\title{
HOUSEHOLD WASTE MANAGEMENT STRATEGY TOWARD ZERO WASTE CITY: A CASE STUDY OF BANDA ACEH
}

\author{
MUHAMMAD NIZAR*1,2, ERMAN MUNIR ${ }^{3}$, IRVAN $^{4}$ AND EDI MUNAWAR*5
}

${ }^{1}$ Department of Natural Resource Management and Environment, Universitas Sumatera Utara, Medan. ${ }^{2}$ Environmental Engineering Department, Universitas Serambi Mekkah, Banda Aceh. ${ }^{3}$ Biology Department, Faculty of Mathematics and Natural Sciences, Universitas Sumatera Utara, Medan. ${ }^{4}$ Chemical Engineering Department, Universitas Sumatera Utara, Medan. ${ }^{5}$ Chemical Engineering Department, Universitas Syiah Kuala, Banda Aceh.

\author{
*Corresponding author: muhammad.nizar@serambimekkah.ac.id \\ edi.munawar@unsyiah.ac.id \\ Submitted final draft: 16 April 2020 Accepted: 22 June 2020 \\ http://doi.org/10.46754/jssm.2021.04.018
}

\begin{abstract}
The list of waste management services offered by the government are growing, but the generation of urban solid wastes is also on the rise. The aim of this study is to develop a strategy to manage household wastes in the city of Banda Aceh based on the five aspects of policy, institutional, funding, community participation, and operational technique. The study was conducted using in-depth interviews with waste management experts and a reviews of national and municipal policy documents dealing with waste management. The investigation revealed that the legal framework for the current municipal waste management system was derived from national and city council plans whereas there is no framework legal or otherwise at the provincial and village levels. From an institutional perspective, the lack of personnel, budget allocation, and coordination among the key stakeholders have weakened waste management institutions. Most notably, funding is vital to managing the huge amounts of waste generated. It is very important to increase stakeholder awareness through improved campaigns and coordination with each other. Meanwhile, technical operations can be improved by sorting out the waste properly, using temporary disposal sites, proper time management and improved waste management logistics. These aspects need to be developed sustainably to save natural resources and reduce or avoid damage to the environment.
\end{abstract}

Keywords: Banda Aceh, household waste, waste management, waste reduction, zero waste.

Abbreviations:

B3 Hazardous materials

$3 R \quad$ reduce, reuse and recycle

DLHK3 Environmental and Cleanliness Agency of Banda Aceh

EPR Extended Producer Responsibility

FGD Focus group discussions

IDR Indonesian Rupiah

ITF Intermediate treatment facilities

$\mathrm{MoU} \quad$ Memorandum of Understanding

PAYT Pay as you throw

IPLT Feces processing plant

TPA Final Disposal/Landfill

TPS Temporary community waste container

TPS3R TPS for reduce, reuse, recycle

UNDP United Nations Development Programme

UU National Law

WCP Waste collecting point

$\mathrm{ZW} \quad$ Zero waste 


\section{Introduction}

The problem of municipal waste management is becoming more and more complex due to the increase in the amount of waste material generated by human activities. In developing countries, poor waste management has had a severe negative impact on the natural environment and public health (de S. Pereira \& Fernandino, 2019)many municipalities present difficulties to sustainably manage their solid waste. The objectives of the present study were to evaluate waste management quality in a coastal municipality in Brazil, Mata de São João, and test the applicability of a system of indicators to reach this goal. A sustainability indicator matrix for municipal solid waste management was used, which was based on the five sustainability dimensions defined by the Brazilian National Policy on Solid Waste (NPSW.

In most Asian countries, waste reduction, especially organic ones, has not been adequately prioritized despite the fact that government policies and available technologies are in place to encourage the proper management of food waste (Joshi dan Visvanathan, 2019). Generally, effective city waste management requires a practical strategy through a well thought out, practical application of the "reduce, reuse and recycle" waste management concept commonly known as 3R (Das dkk., 2019). Similarly, the Zero Waste concept can also help to reduce municipal waste. This involves putting in an effort towards ensuring a reduction in the generation of waste, so as to minimize the quantity of waste in landfills (Zaman, 2014).

The Zero Waste city concept does not rely on incinerators or landfills and aims to bring an end to the "throwaway society" and create sustainable communities. However, utopian this may sound, the government of Banda Aceh is determined to make it work, becoming a Zero Waste city may not be achievable within a year but with the implementation of a holistic strategy, Banda Aceh aims to move be much closer to a zero waste target (Connett, 2007). This strategy focuses on five aspects: a legal framework, institutional backing, proper funding, community participation, and operational or technical aspects.

The provision of a good waste management infrastructure relies heavily on increasing citizens' awareness about the scarcity of resources and available recycling options. Additionally, recycling programs have the potential to improve the effectiveness of community waste management.

In fact, the " $3 \mathrm{R}$ " concept is very important for the reduction, or proper utilization of waste products via separation, segregation and recycling (Babaei dkk., 2015)attitudes, and practices (KAP. However, the challenges involved in implementing these practices in developing countries are greater than those in developed ones. Therefore, some scientists believe that the success of these actions will be largely influenced by people's recycling behaviour (Tiew dkk., 2019)the latest national recycling rate in Malaysia rose from 5\% in 1993 to approximately $24.6 \%$ in 2017 . However, the practice of solid waste recycling in developing countries is still challenging compared to developing countries. Especially in Malaysia, a multi-ethnic country where people with different ethics have different living lifestyles. Still, Malaysia faces rapidly increasing solid waste and management costs, lacks appropriate data on solid waste management and recycling, lacks awareness of the 3R's (reduce, reuse and recycle.

Waste management strategies in some developing countries involve the use of both formal and informal methods. Unfortunately, the development of a management strategy requires data obtained from comprehensive studies which are not readily available in developing countries.

Moreover, it is very difficult to reduce municipal waste without the proper infrastructure and organization (Mesjasz-Lech, 2019; Erfani et al., 2019). In developing countries, a faith-based approach should be considered as one of the ways to educate the public on waste programs. Having said this, many waste management programs are hampered by funding problems in 
developing countries, causing those programs to obtain sub-optimal results (Zamri et al., 2019).

Developing countries also rarely evaluate waste management policies due to the lack of available data (Cetrulo et al., 2018). On the other hand, developed countries often conduct evaluations to assess the success of their waste reduction programs. On top of that, they implement environmental and economic approaches in their waste programs (Zamri et al., 2019).

Research on waste generation can contribute to the effectiveness of municipal waste management initiatives (Pham Phu et al., 2018). Developed countries, which have sufficient funds, rely heavily on technology to manage waste such as turning waste into energy, while developing countries often lack proper waste management equipment or infrastructure and must involve the informal sector such as scavengers to help with the management of waste disposal Developing countries also do not specifically regulate waste management according to the type of waste, for example the disposal of plastic or electronic waste.

Plastic waste has become a major waste problem in developing countries due to a lack of readily available collection and recycling systems (Kumi-Larbi et al., 2018). It can be said that rural waste management is still a challenge for developing countries (Han et al., 2018).

Although there are different strategies available to handle waste disposal, they all have the same goal, of achieving sustainable development (Nizar, Munir, Irvan et Waller, 2018). Therefore, each country should use a different approach based tailored to fit the local context (Ogunmakinde, 2019). However, regardless of the approach, it is important to consider the financing of these waste management systems in order to ensure their sustainability (Ferramosca, 2019).

Likewise, the involvement of the local community is a vital strategy, especially considering the fact that waste is generally generated by the community as it goes about its daily activities (Malik, Abdullah, \& Manaf, 2015; Dhokhikah, Trihadiningrum \& Sunaryo, 2015; Chakrabarti, Majumder \& Chakrabarti, 2009)sustainability of the system cannot be ensured, even when introduced in areas with a smaller size of operation because of voluntary services provided by the communities, low involvement of private agencies and inappropriate choice of methods for waste recycling. Operational efficiency may be achieved by involving the private sectors on a larger scale along with community people and by including the provision for payment of incentives/subsidies to them in exchange of services rendered. Possibilities of implementing the system have been explored in this study on households residing in the Baranagar Municipal (BM.

In early May 2008, the Indonesian government passed a "catch-all" broad spectrum national law that governs waste management, commonly known as Law 18, 2008.

Despite this, waste management is still a challenge for the Indonesian government. Nationally it is estimated that only between $60 \%$ and $70 \%$ of the total urban waste generated can be transported to a landfill by authorized government agencies.

Furthermore, there are still many waste concepts that have not been properly implemented and have only generated suboptimal results.

To date, the parameters used to assess the effectiveness and efficiency of Zero Waste policies in Indonesia deal with waste avoidance; extended producer responsibility, pay-as-youthrow community waste management and providing incentives as well as disincentives for proper waste management or the lack thereof respectively (Damanhuri, 2005).

Considering the points, it can be inferred that the strategy to achieve Zero Waste in the city of Banda Aceh is expected to rely heavily on a proper legal framework, institutional backing, proper funding, community participation, and operational or technical aspects in line with 
current environmental conditions to ensure the targeted reduction in waste generated is achieved.

Therefore, several waste management experts in the city were interviewed in-depth to obtain information on the current state and future plans with regards to waste management in Indonesia.

In addition, this study also looked at policy studies at the national and village levels with the aim of developing several household waste management strategies to address the issue of sustainable waste management. This study was carried out in Banda Aceh, Indonesia from 2017 to 2018 .

\section{Geography of Banda Aceh}

Banda Aceh is located at the northwestern tip of the island of Sumatra, Indonesia with a latitude of 5.56 and longitude of 95.32 , it sits 8 meters above sea level. This city is the capital of Aceh Province, having an area of $61.36 \mathrm{~km}^{2}$ and a population of 254,904 people, with a density level of $4,154.23$ people $/ \mathrm{km}^{2}$.
Figure 1 shows the geographic location of the study area of Banda Aceh in relation to Indonesia. The study area is categorized as a middle city (Kementerian Pekerjaan Umum, 2013) and the land of Banda Aceh is divided into several categories as shown in Figure 2.

The number of households in the city is 74,534 with much of the population living in individual homes. Vertical housing complexes such as flats consists of 384 units usually built in 4 blocks while a small portion inhabits shop houses consisting of two or three floors. Villages in Banda Aceh have small roads or aisles, usually only 3 meters wide, while main roads accessible by waste transport trucks is between 6 and 8 meters wide.

The types of housing and residence are important to determine efficient and effective waste collection systems. On the other hand, the types of settlement affect the location of temporary waste containers (TPS), construction of recycling centres, and transportation modes.

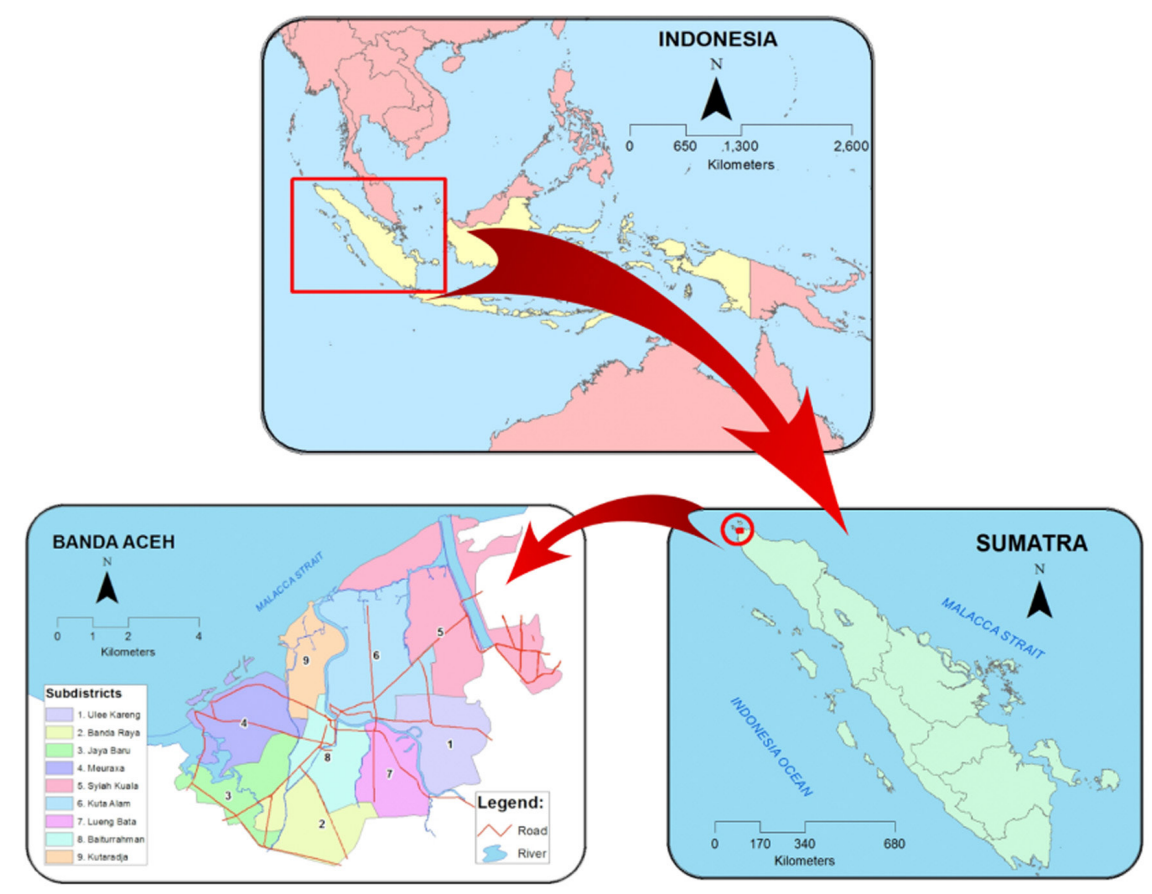

Figure 1: Geographic location of Banda Aceh, Indonesia 


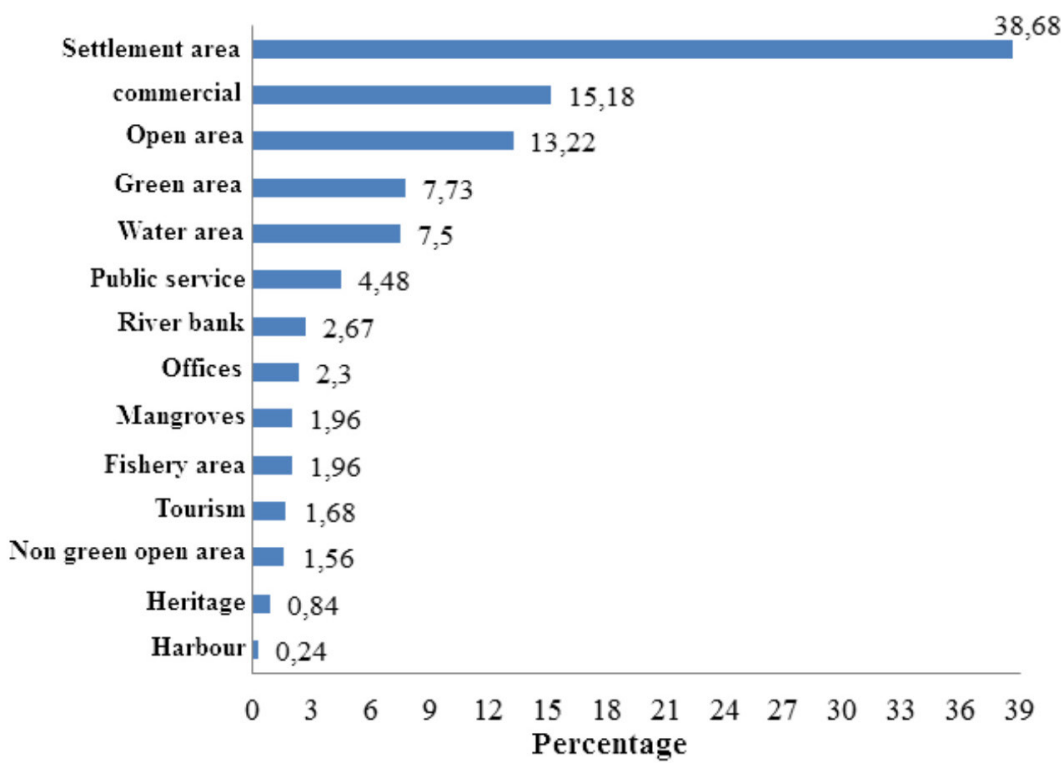

Figure 2: Percentage of the area of Banda Aceh city by land use (Badan Pusat Statistik, 2018)

There is no large-scale industry in the city but there are small-scale household industries such as tofu and tempeh factories, which mean that all the waste generated comes from households. Banda Aceh has seven traditional markets at Kampung Baru, Rukoh, Lamnyong, Peunayong, Seutui, Ulee Kareng, and Kampung Ateuk where wastes generated are transported to the Kampung Jawa landfill. There are other trading centres such as supermarkets, malls, and shops scattered throughout the city. The income per capita is IDR26 million/capita/year, which is below the national average of IDR42 million/ capita/year. The percentage of poor people in the city stood at $7.41 \%$ in 2016 and the population growth rates in 2014, 2015 and 2016 were $0.09 \%, 0.32 \%$, and $1.84 \%$, respectively, while the rate of economic growth for the same years were $4.50 \% ; 5.01 \%$ and $6.31 \%$, respectively.

Generally, the population's income affects purchasing power, which consequently increases the potential for waste generation. However, other factors that will be discussed later also contribute to the quantity of waste produced in the city.

\section{Banda Aceh City waste management}

Banda Aceh City's waste management is handled by two parties which are the City Government through the Banda Aceh City Environment and Cleanliness (DLHK3), and the community. DLHK3 manages municipal solid waste in a structured manner, while the community does it sporadically with some of the effort requiring subsidies from the government.

The participation of the residents in Banda Aceh in proper waste management is low. This is reflected by their poor waste management habits such as not disposing garbage into garbage cans, not sorting or recycling the garbage and the irregular payment of fees to waste disposal service providers.

Currently, the average total daily waste entering the Kampung Jawa landfill stands at 168 tonnes. The level of waste serviced by DLHK3 is as shown in Table 1.

The biggest composition of municipal waste is food which accounts for $39.5 \%$ of the total waste. Figure 3 shows the percentage of waste composition in landfills from different sources in the city. 
Table 1: Services provided by DLHK3 Banda Aceh (PT. Multi Karadiguna Jasa, 2018)

\begin{tabular}{lcc}
\hline \multicolumn{1}{c}{ Parameter } & & Unit \\
\hline Village area & 100 & $\%$ \\
Community coverage & 83,5 & $\%$ \\
Door to door homes & 74 & village \\
Service object & 152,944 & home/store/office/etc \\
Transportation Frequency & $2-4$ & trip/day \\
Frequency of transportation for & $1-2$ & trip/day \\
village retribution areas & & \\
\hline
\end{tabular}

The government achieved the target of reducing the quantity entering landfills by $11 \%$ in 2015 and this figure was increased to $15 \%$ in 2016 (Muhammad Nizar, Munir, Irvan dan Amir, 2019).

The Indonesian government has also set an ambitious target of 30\% for 2025 (Walikota Banda Aceh, 2018).

There is a direct individual waste transportation system where janitors move from door to door for waste collection, transportation, and disposal to the landfill site. This is mostly observed in residential neighborhoods on main roads, shopping areas, public facilities, main roads, and parks. Moreover, communal waste management system involves the collection of household waste to the TPS and transportation by janitors to the landfill.
A relatively new system was introduced using the community recycling centre. It involves the delivery of waste by residents to the recycling centre located normally 10 to 20 meters from the settlement. Non-recycled waste or residue are collected by DLHK3 to be disposed in landfill.

Waste collected from all over the city are disposed at the Kampung Jawa landfill located approximately $3 \mathrm{~km}$ from downtown. The landfill occupies 21 hectares of land with 12 hectares already utilized. The landfill was destroyed when the tsunami struck in 2004, but it was rebuilt by implementing a controlled landfill system in January 2009. Every year it takes $5000 \mathrm{~m}^{3}$ of soil to cover the surface of the waste and $3500 \mathrm{~m}^{3}$ of compost to reduce odour from the landfill (DLHK3 Banda Aceh, 2017b).

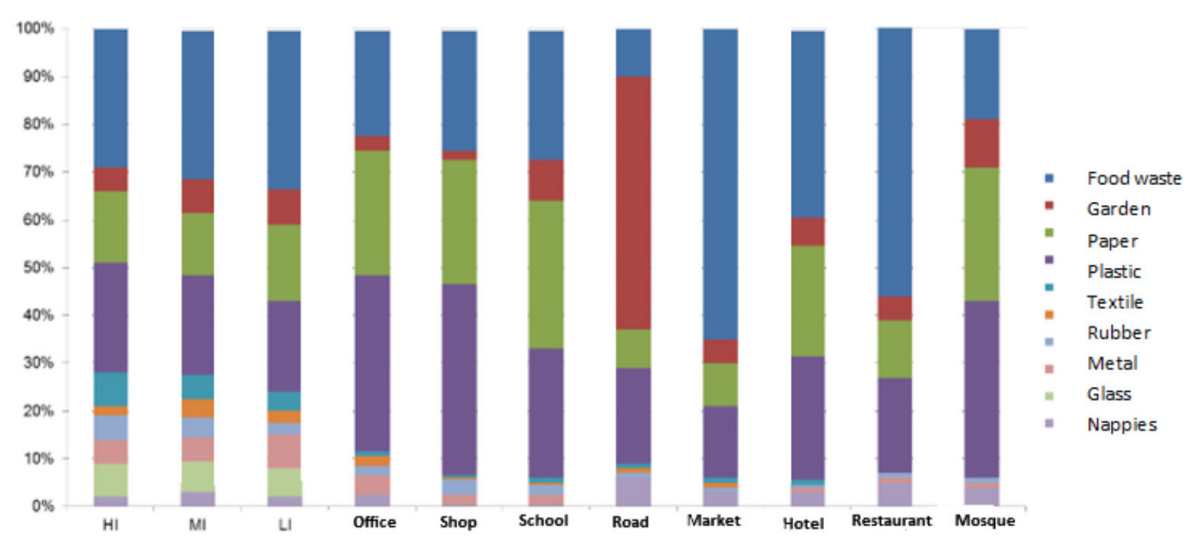

Figure 3: Percentage and composition of waste in Banda Aceh

HI: high income household, MI: Medium income houseold, LI: Low income household

(PT. Multi Karadiguna Jasa, 2018) 
The conditions of the landfill are shown in Table 2.

The waste is transported from the TPS using dump trucks, pick up cars, tricycles or garbage carts and compactor trucks. DLHK3 employs 97 cleaners and some of them are street sweepers. The revenue from garbage fees paid by 142,342 customers amounted to Rp.3,878,861,500 and the service coverage of DLHK 3 reaches $88 \%$ of the population of the city (DLHK3 Banda Aceh, 2016). The landfill has an Intermediate Treatment Facility (ITF) that processes 20 tonnes/ month of organic waste, generally obtained from the community, into compost. DLHK3 also has a depot that receives $69,650 \mathrm{~kg}$ of recycled plastic bottles/ year. Since 2015, the Kampung Jawa Landfill has also been distributing methane gas produced as a byproduct of the decomposition of waste at the landfill to the communities around the area. Channeling was conducted to ensure that the methane gas does not cause pollution, instability in the waste pile structure reduce the risk of landslides and the high risk of fires. The landfill is the first disposal site (TPA) in Indonesia to harvest methane gas and distribute it as fuel to nearby communities as shown in Figure 4.

Table 2. The condition of Kampung Jawa landfill

(DLHK3 Banda Aceh, 2018)

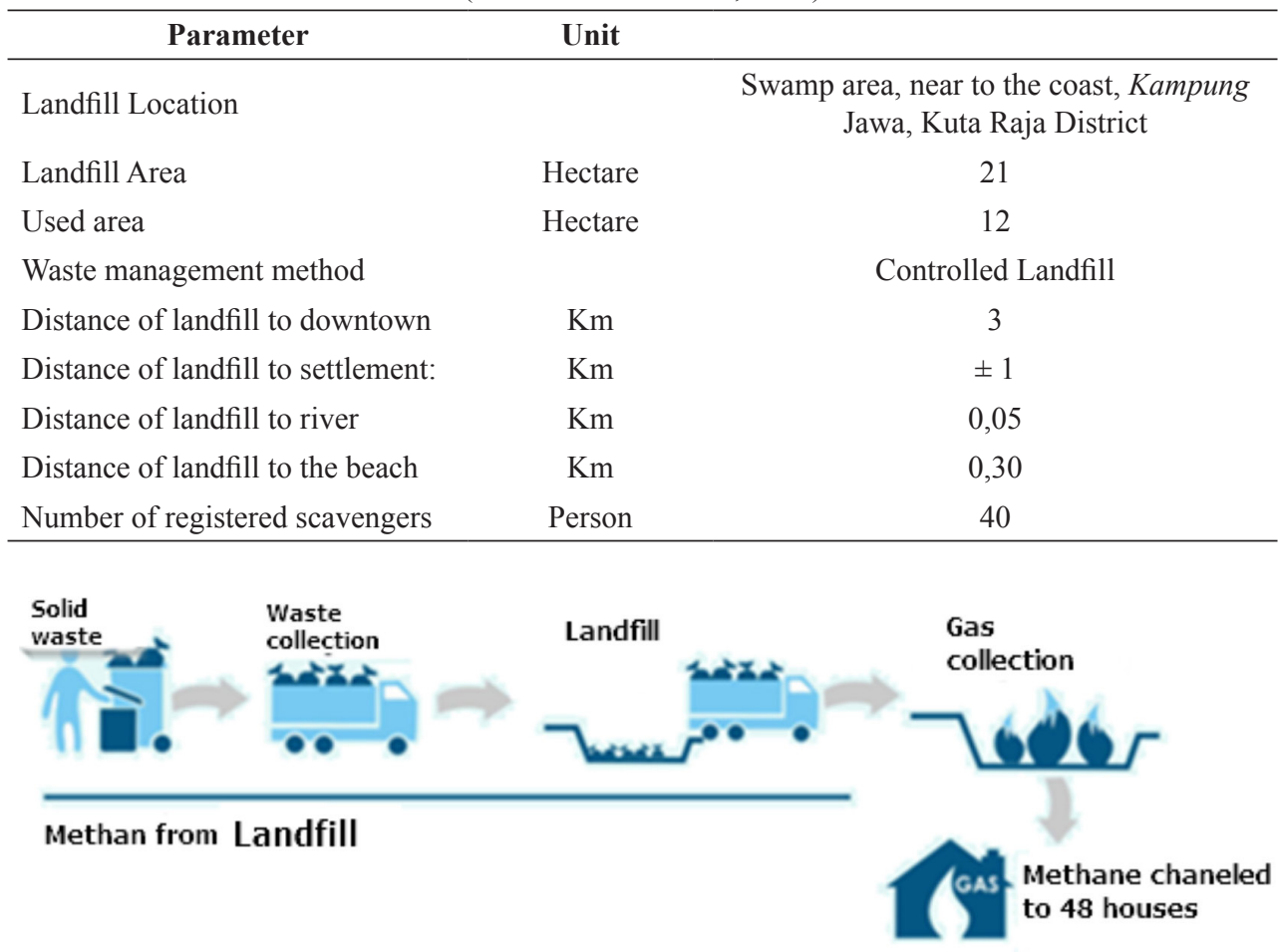

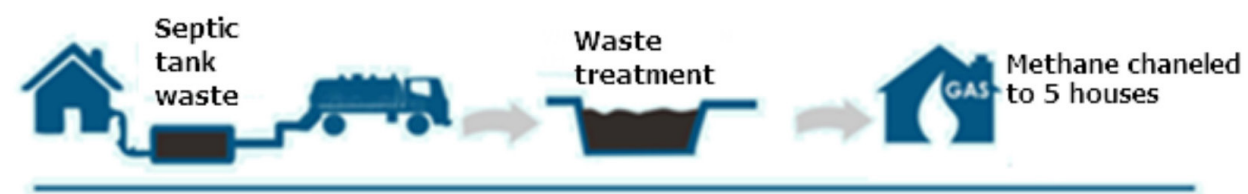

Methan from IPLT

Figure 4: Scheme for the use of waste to energy in TPA Kampung Jawa (DLHK3 Banda Aceh, 2016) 


\section{Waste management by the community}

Households sort waste according to at least two categories, organic and inorganic. Some may do this in more detail, for example separating metal, paper, plastic and Toxic Hazardous Materials (B3).

The community processes organic waste into compost which is used as fertilizer while those from households such as food scraps, fruit skins, vegetable scraps, fats and dairy products are mixed with garden waste at a certain proportion to produce good compost for household-scale usage.

However, compost from food has low organic component stability (Kucbel dkk., 2019). The government helps the community in setting up waste banks and management centres in four villages and 35 schools have waste banks.

In addition, there are two models of management by the community, and they are Reuse, Reduce and Recycle Centre (TPS3R), and Waste Collecting Point (WCP).

The sole difference between the systems is the method of collection. Specifically, the use of TPS3R requires officers going to the houses to collect rubbish while with the WCP, residents are required to carry their wastes to the WCP points in the village. The service coverage for the systems is small with only two locations, Alue Deyah Tengoh and Deyah Geulumpang, for WCP while TPS3R covers the area of Lambung and Surien (DLHK3 Banda Aceh, 2017).

The city government has established the WCP legally by way of a Mayoral Regulation No. 7, 2017 which deals with Guidelines for Implementing Community-Based Waste Management and Waste Collecting Point System (Pemko Banda Aceh, 2017).

\section{Waste Stakeholders}

Solid waste stakeholders are involved in planning, policymaking and managing waste in Banda Aceh. They comprise of both governmental and non-governmental organizations, as well as the community. The private sector is involved in commercial management such as the buying and selling of used goods and this means they are almost not involved in the planning process. DLHK3 is responsible for waste management programme by providing facilities and infrastructure and funds while other stakeholders are involved through invitation by the city government.

The community conducts small scale management as observed at the village level while households engage in sorting, reusing, reducing and recycling processes. In short, the

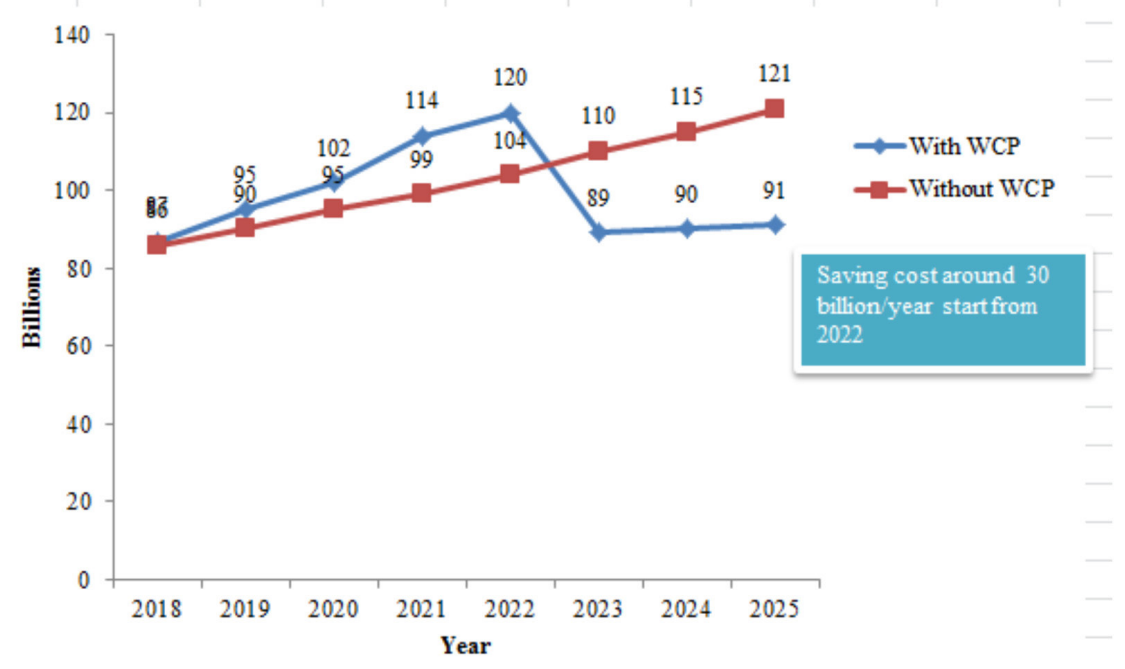

Figure 5: DLHK3 waste management roadmap (DLHK3 Banda Aceh, 2016) 
waste recycling centres are managed by the community with support from the government while non-governmental organizations are more focused on raising public awareness through different programs. The practices of these stakeholders have implications for reducing waste management costs. For example, Figure 5 shows the cost reduction by DLHK3 as a result of applying the waste collection point concept (WCP).

The implementation of a WCP system initially required a lot of funds to set up the required infrastructure and undertake promotion campaigns to raise public awareness. However, in recent years, the need for funds has decreased due to a reduction in the amount of waste generated by the community. Eventually, the WCP system will become cheaper to finance than non-WCP systems because in its absence, more waste generation was disposed to landfills.

The role of stakeholders is very important to the success of waste management initiatives as each of them has an active role to play in ensuring a reduction of waste generation from their respective areas. This active role helps the government and reduces the costs (Wilson, Velis and Cheeseman, 2006 ; Babaei, et al., 2015) attitudes, and practices (KAP.

\section{Regulations Regarding Zero Waste}

Regulations on Zero Waste are passed to reduce waste dumped into the landfill and the parameters included in the Banda Aceh Qanun or municipal regulations include waste segregation, extended producer responsibility (EPR), a pay-as-youthrow scheme, as well as waste management by the community and incentives scheme.
The Republic of Indonesia Law Number 18, 2008 on Waste Management (UU No.18 Tahun 2008) was passed and, subsequently, the City of Banda Aceh approved the new Banda Aceh municipal regulation No. 1, year 2017 concerning Waste Management (Qanun Kota Banda Aceh Nomor 1 Tahun, 2017). The municipal regulation includes Zero Waste parameters and mentions plastic bag restrictions not stated in the Republic of Indonesia Law Number 18, 2008, on Waste Management.

In addition to municipal regulation No. 12017, there is also Banda Aceh Waste Retribution Regulation No. 5, 2017, and Mayoral Regulation No. 7 Guidelines for Implementing Community Based Waste Management and Waste Collecting Point System, 2017 and Mayoral Regulation No, 46 Policies and Strategies for Managing Household Trash and Similar Waste, 2018.

\section{Material and Methods}

\section{Methods}

This study was conducted in Banda Aceh for duration of 12 months from April 2017 to March 2018. The initial stage of the study involves secondary data collection, followed by field observations, interviews with experts and Focus Group Discussions (FGD). Data collected from these activities was processed and analyzed before the findings are compiled into this report.

The experts interviewed were selected from a range of academics, practitioners and government employees who have been involved in waste management for a minimum of 2 years. This selection was conducted using the

Table 3: Characteristics of the study respondents

\begin{tabular}{lll}
\hline \multicolumn{1}{c}{ Category } & \multicolumn{1}{c}{ Number } & \multicolumn{1}{c}{ Data type } \\
\hline Academicians & 3 persons & In-depth interview \\
Practitioners & 8 persons & In-depth interview \\
DLHK3 staff & 3 persons & In-depth interview \\
FGD with academicians and & 2 times & In-depth discussion \\
practitioners & & \\
\hline
\end{tabular}


snowball method to obtain a total of 16 expert respondents. Table 3 shows the characteristics of respondents and type of research data.

The waste policy documents reviewed include Republic of Indonesia Waste Management Law No. 18, 2008 Waste Management Regulation No. 1, 2017, Waste Retribution Regulation No. 5, 2017, Banda Aceh Mayoral Regulation No. 7 year 2017 concerning Guidelines for Implementing CommunityBased Waste Management and Waste Collecting Point Systems and several related policies.

All information obtained was processed using NVivo qualitative data processing software as shown in Figure 6.

The qualitative data were grouped in certain files to facilitate the search for topics. Furthermore, based on keywords, data were extracted and collected in other files to store those with the same or related keywords in one file.

\section{Results and Discussion}

The study focused on finding strategies for household waste management according to the concept of Zero Waste. The management strategy reviewed considered the current situation using Waste Law No. 18/2008 as well as applicable local policies. The ability to manage solid waste was assumed to develop regularly with the baseline from 2012 to 2025 in accordance with the Regional Strategy Policy of Zero Waste management.

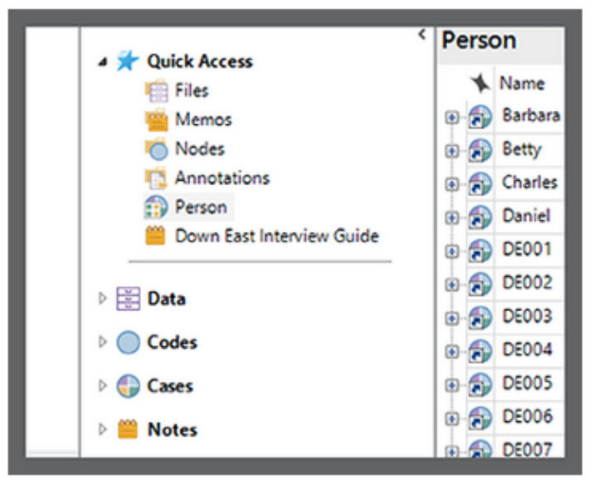

Figure 6: NVivo data processing software scheme

\section{Policy Aspects}

Banda Aceh's municipal waste management has a legal foundation from the national and city levels. At the national level, several policies have been issued up to the ministerial level and the systematic legal basis as shown in Table 4 limits national rules to the presidential level. There is, however, no legal basis for waste management at the provincial and village levels despite their importance in developing a strategy to improve the process.

Policies at the provincial level can order all regions below both regencies and cities to conduct waste management as much as possible. Through the implementation of Waste Management bylaws, the city has been able to act progressively and be more detailed in making rules to govern waste management.

For example, the city of Bandung, Indonesia, has been able to effectively prohibit the use of styrofoam for food and beverage packaging from November 1, 2016.

Aceh Province, as a special autonomous region in accordance with Government of Aceh Law No. 11, 2006 could regulate waste management even more effectively. Moreover, the government provides it with room to enact a slew of waste disposal regulations to ensure good compliance with the principles of Zero Waste.

Additionally, each village in Banda Aceh can make more operational waste management bylaws called reusam, which can bind the

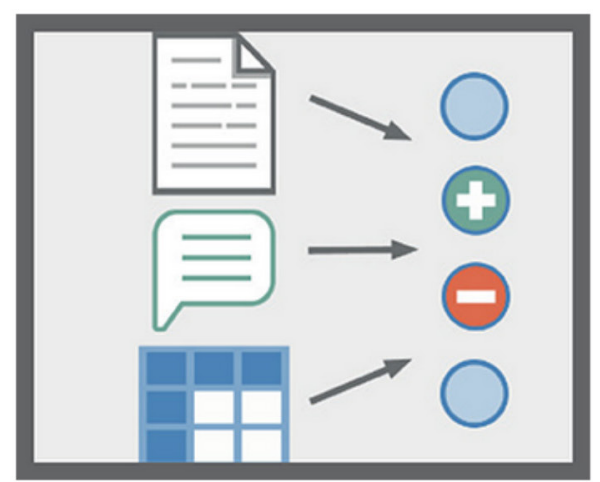

Journal of Sustainability Science and Management Volume 16 Number 3, April 2021: 257-275 
Table 4: Legal basis for waste management from national - local

\begin{tabular}{|c|c|}
\hline Level & Legal basis \\
\hline \multirow[t]{4}{*}{ National } & 1. Law of the Republic of Indonesia Number 18 Year 2008 Regarding Waste Management \\
\hline & $\begin{array}{l}\text { 2. Law Number } 23 \text { Year } 2014 \text { Regarding Local Government (including management } \\
\text { authority) }\end{array}$ \\
\hline & $\begin{array}{l}\text { 3. Presidential Regulation of the Republic Indonesia Number } 97 \text { Year } 2017 \text { Regarding } \\
\text { National Policies and Strategies for Managing Household Waste and Similar Household } \\
\text { Waste. }\end{array}$ \\
\hline & $\begin{array}{l}\text { 4. Republic of Indonesia Government Regulation Number } 81 \text { Year } 2012 \text { Regarding } \\
\text { Management of Household Waste and Similar Household Waste. }\end{array}$ \\
\hline Provincial & Not available \\
\hline \multirow[t]{5}{*}{ City } & 1. Banda Aceh Qanun Number 1 Year 2017 Regarding Waste Management \\
\hline & 2. Qanun Number 5 Year 2017 Regarding Waste Retribution \\
\hline & $\begin{array}{l}\text { 3. Banda Aceh Mayor Regulation Number } 46 \text { Year } 2018 \text { Concerning Policies and } \\
\text { Strategies for Managing Household Waste and Similar Waste }\end{array}$ \\
\hline & $\begin{array}{l}\text { 4. Banda Aceh Mayor Regulation Number } 61 \text { Year } 2018 \text { Concerning Policy on Banda } \\
\text { Aceh City Waste Management Strategy 2018-2025 }\end{array}$ \\
\hline & $\begin{array}{l}\text { 5. Banda Aceh Mayor Regulation Number } 7 \text { Year } 2017 \text { Regarding Guidelines for } \\
\text { Implementing Community Based Waste Management with a Waste Collecting Point } \\
\text { System }\end{array}$ \\
\hline Village & Not available \\
\hline
\end{tabular}

residents more strictly to the rules. The authority to formulate the rules is guaranteed by the laws governing the province of Aceh, and the villages are encouraged by the government to create waste management reusam through the provision of facilities.
Figure 7 shows the scope of the policy from national to village level and smaller areas are observed to have more operational policy according to the need of the local community.

National policy becomes the legal basis for other policies below it, for example, district/

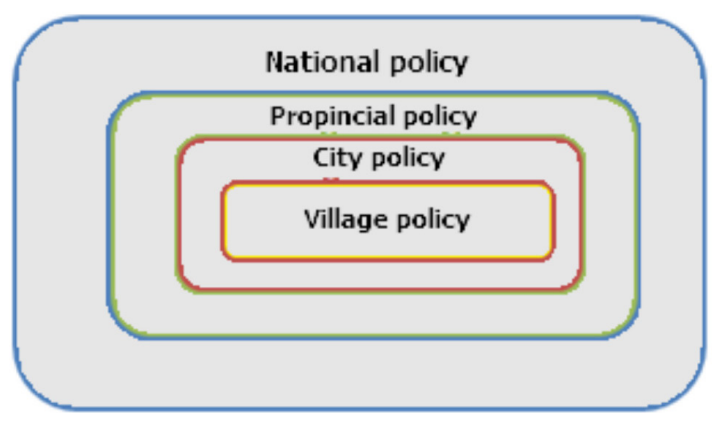

Figure 7: Waste management policy scope 
city and village level policies. Policies at the lower level must not conflict with the policies above and must be aligned. Usually the more the policy is at the lower level, the more detailed the policy will be. Each regional level can make its own waste policy according to the context of each region.

Waste management policies in Indonesia are generally still focused on collecting garbage and transporting waste from the community to landfill. However, the policy in Banda Aceh City has more specifically mentioned the method of separating waste from sources as a step to reduce waste. Based on observations in the field, waste sorting has not gone well because generally various types of waste are mixed in one container.

In a particular study conducted by Han and Zhang (2017) in China, waste separation policy was reported did not cause a significant reduction in waste but separation at the source has provided a strong foundation for the application of the $3 \mathrm{R}$ principle. In addition, waste separation was considered the best approach to reduce the burden on landfills, in response to growing pressure from waste generation because of industrialisation, urbanisation and economic growth. Hence, the government needs to facilitate public participation in segregation at the waste source by integrating several policies which combine voluntary or mandatory participation.

\section{Institutional Aspect}

Weak institutional performance is observed in the lack of management capacity personnel and budget allocations to promote good waste management. The absence of cooperation and coordination among institutions have been observed to influence stakeholders' contribution to the performance of waste management (Spoann, Fujiwara, Seng dan Lay, 2018.

Undoubtedly, the institutional aspect is very important to zero waste strategy due to the roles of the institutions in determining the quality of daily performance and the biggest portion of the responsibility of managing waste in the city of Banda Aceh is on DLHK3 with others conducted by the community.

In essence, it is not possible to impose complete responsibility by the government alone, given that waste is produced by everyone, anywhere and anytime. However, one step to strengthen the performance of DLHK3 is to establish a minimum permanent waste management institution, at least up to the subdistrict level, due to the professionalism the process requires as well as other development sectors. These institutions can either be established by the private sector or through inter-regional cooperation.

The government, as the regulator, gives authority to the private sector to manage waste in certain areas and conduct supervision. Some developed countries implement cooperation with the private sector by focusing on processing, recycling, and processing costs while the government focuses on regulation. The collection and processing costs are managed through income from waste fees and the sale of recycled goods (Mohan, Sinha dan Lal, 2016) requiring urgent solutions, especially in view of rapid urbanization and inability of local urban authorities to tackle it. Saharanpur, a small city in Uttar Pradesh, represents a microcosm of most large cities and towns in India, grappling with similar challenges. With a decadal population growth of over 19\% during 2001-2011, which is higher than the national growth, the city is confronted with the task of managing a rapid growth in solid waste. In order to come up with viable solutions to this problem ITC Limited, in collaboration with Muskan Jyoti Samiti, an NGO, and the local municipal authority, initiated a pilot PPP project on solid waste management in the year 2006. With persistent focus on processing, recycling and user fee, this initiative has been able to surpass the national benchmark of $80 \%$ waste recovery set by the Ministry of Urban Development (MoUD.

Waste retribution, although managed privately, needs to be based on fairness principle. For example, the application of 
quantity-based waste retribution regardless of demographic characteristics, knowledge, and attitudes towards waste management (Chung \& Yeung, 2019). Furthermore, cooperation between adjacent regions needs to be ensured to synergize on waste management. For example, due to the proximity of the borders of Banda Aceh and Aceh Besar, the TPS can be placed together, and the regional landfills utilised by the residents of the two regions. Ideally, the agreement needs to be detailed, not just to make a $\mathrm{MoU}$ to transport waste into the regional landfill without the concept of waste reduction and disseminated to the people of both regions. Table 5 shows likely institutions to be formed in managing waste according to level.

Notably, the concept of cooperation has been regulated in Waste Management Law No.18, 2008 where the provincial government facilitates cooperation between regencies/ cities by forming regional landfills. This joint institution was formed as the final handling of waste due to the continuous increase in the limitation and cost of land.

\section{Fund Aspect}

The equitable application of funding in the waste management system is to support the sustainability of the program from an economic perspective. Adopting a pay-as-you-throw (PAYT) model makes it possible to increase the coverage of the services compared to the flat fee model.

Besides, innovative technology can be funded to improve the efficiency of the services. Unit prices, user identification, and waste measurement are the three most important processes to be defined in the PAYT system (Elia, Gnoni \& Tornese, 2015).

So far, the waste management fund has been fully funded by the city government through the city council budget. The funds provided by the city council were inadequate both because of political reasons and competition between sectors. The source of funds for waste management only comes from waste fees that have a flat retribution value.

Study results show the waste management cooperation covers a very small portion of the total DLHK3 budget at $2.96 \%$, the increment of community participation is $7.76 \%$, and development of $3 \mathrm{R}$ management is $3.39 \%$, involving 50 households out of a total of 74,534 households in Banda Aceh.

Although the Banda Aceh city government had complained about the lack of funds in the waste sector, no initiative was initiated towards increasing funding from and for the sector. Unfortunately, the main income from retribution cannot cover operational costs (Irwansyah, Syahputra, Nadir dan Bakri, 2017). Therefore, steps are required to increase funding as a means of controlling the volume of waste generated. Interestingly, based on the stipulation of flat retribution in Waste Retribution Regulation No. 5 2017, it is possible to maximize the potential of user fees.

Moreover, the use of online payment is now common as well as the combined system where the money is paid with other utilities like water bills because they share the same customers. This model is possible because the

Table 5: Waste management institutions at various levels

\begin{tabular}{ll}
\hline \multicolumn{1}{c}{ Level } & \multicolumn{1}{c}{ Institution } \\
\hline City & 1. Government (DLHK3) \\
& 2. Private \\
& 3. Community \\
Subdistrict & 1. Community (TPS3R, waste bank, Waste Collecting \\
& Point) \\
Village & 2. Private \\
\hline
\end{tabular}


two institutions managing them are under the same Banda Aceh City Government.

Another possible strategy is to provide subsidies to collectors of used goods. This is because economic factors are a powerful driver for people working in any field. Unfortunately, working with solid waste is less desirable due to negative impression, especially with regards to low income earned by used goods collectors despite their maximum potential.

As a possible solution to this issue, the government can set up depots to receive used goods at a price slightly above the market price without disrupting the market balance. In addition, a valuable "garbage" pick-up programme can be created in the community to obtain income from wastes.

Through using the subsidies strategy, Pietzsch et al. (2017) reported that it is possible to minimize costs and raise revenues from waste management in the city. Specifically, less waste generated due to its separation from its source, less environmental recovery costs and losses related to inefficient management, and increased profits from the sales of recycled materials. Another economic benefit from the implementation of zero waste focuses on increasing income from the emergence of jobs related to waste management.

\section{Community Participation Aspect}

The community needs to play a greater role in waste management to ensure optimal reduction. Specifically, their responsibilities include conducting solid waste campaigns, stakeholder participation, and coordination between communities (Spoann dkk., 2018). In general, garbage is expected to be properly managed by the government after the payment of specified fees by the residents with only a few conducting waste management practices independently. However, when the levy was raised to meet the costs of management, the community rejected it due to their belief that it is possible to manage wastes at a low cost.
This is inversely proportional to the levies of other sectors, where people are more receptive to tariff increases. Moreover, community participation was often found to be very poor regarding waste sorting and disposing of garbage according to its type. Improper disposal of waste is often observed in Banda Aceh despite the markings on bins, for example. Other observations in this research found that the sorting bins are not being used according to their functions, as people generally throw wastes into incorrect bins even though they are provided with codes and colors according to the type of waste. The community must be made more responsible but unfortunately waste campaign, education, promotion, and appeals are found to be sporadic in certain events.

Even though garbage is produced by everyone every day, more massive, intensive, and regular campaigns, education, as well as promotion and awareness on the importance of waste management, is required by the community.

Research conducted at Universiti Kebangsaan Malaysia on students receiving solid waste education showed that $60 \%$ of them adopted a positive attitude towards waste reduction programs. The students demonstrated high-levels of responsibility and practiced proper waste management on campus, therefore, education strategies and student awareness programs must be developed to change habits and behaviours towards the management of waste (Desa, Kadir \& Yusooff, 2012).

Moreover, the city government needs to undertake social engineering to improve the mindset of the community about the management of waste by building a 3R Centre in one subdistrict, because a minimum of $300 \mathrm{~m}^{2}$ of land is required to ensure economic sustainability. The construction of the 3R Centre will allow waste issues to be closer to the community (Kementerian Pekerjaan Umum, 2013) because every settlement or village in the city area has its waste management system to reduce the amount of waste going into landfills. The 3R Centre is managed by the community with government 
support, if sub-district does not have a $3 R$ centre, then the involvement of the community in managing waste is not optimal.

\section{Technical Operations Aspects}

This is currently the aspect that is most visible to members of the public due to its relation to technology, transportation methods, landfills, waste management, and others. Banda Aceh City is quite good at providing equipment and manages its waste quite well and this makes it easy for the government to improve operational techniques to ensure more effective and efficient management. Fig. 8 shows the facilities and infrastructure currently owned by DLHK3 Banda Aceh.

The improved technical aspects of the city's waste management operation are as follows:

1) Sorting of waste products: The government provides user-friendly, easily understood, and easy to handle segregated trash bins for the public. These bins are designed to facilitate the easy movement of trash into the transporter. This is, however, often ignored, causing a scattering of waste during transfers between bins.

2) Temporary Disposal Sites: Provision of communal containers containing the volume of the surrounding community's waste, whose sanitation is maintained, with technology which can accommodate people's waste disposal habits.

3) Waste transportation: The types of waste transport vehicles are in accordance with the geographical conditions and type of road, and others to maximize the transportation of waste. This transporter needs to maintain cleanliness to ensure garbage is not scattered in transit. The city does not currently have a dedicated waste transporter but provides compactor trucks instead.

4) Time management of waste transportation: Timely transport management can encourage disposal of wastes at a specific time. In the initial stages, the government can fix the waste collection time to certain hours in the morning and evening after which the residents will not be allowed to put wastes outsides the home, but in a hidden place to avoid pollution. This rule must be firmly applied to instill discipline in waste disposal and making the environment clean.

5) No-single use material campaigns: Avoid using materials that generate unnecessary waste through a process known as "less waste event", where the use of disposable materials such as plastic cups, plastic bags, and others are avoided. If the avoidance of disposable materials becomes a habit, waste reduction will be significant.

Numerous groundbreaking approaches have been identified for the implementation of smart and efficient waste management systems in many countries. Inefficient waste logistic networks make it impossible to handle the ingress and discharge of solid waste from a waste dump to a treatment facility and vice versa. The level of sweeping and waste disposal is closely linked to the economic status of a nation (Das dkk., 2019).

Such state-of-the-art methods are largely unworkable in developing countries due to their high costs requires financially viable supportive policies and subsidies (Hietala et al., 2018; Christensen and Bach, 2015.

The aim of a sustainable waste management programme is to shift from conventional waste dumps that are expensive and harmful to the environment to sound waste management programmes that maintain valuable resources within the economy (Kumar dkk., 2017).

\section{Conclusion}

Strategic preparation made up of five aspects namely legal foundation, institutional, funding, community participation and operational technique can significantly reduce household waste. Therefore, it is recommended that they are applied simultaneously due to their interrelation. This is because if only a few aspects are applied, 


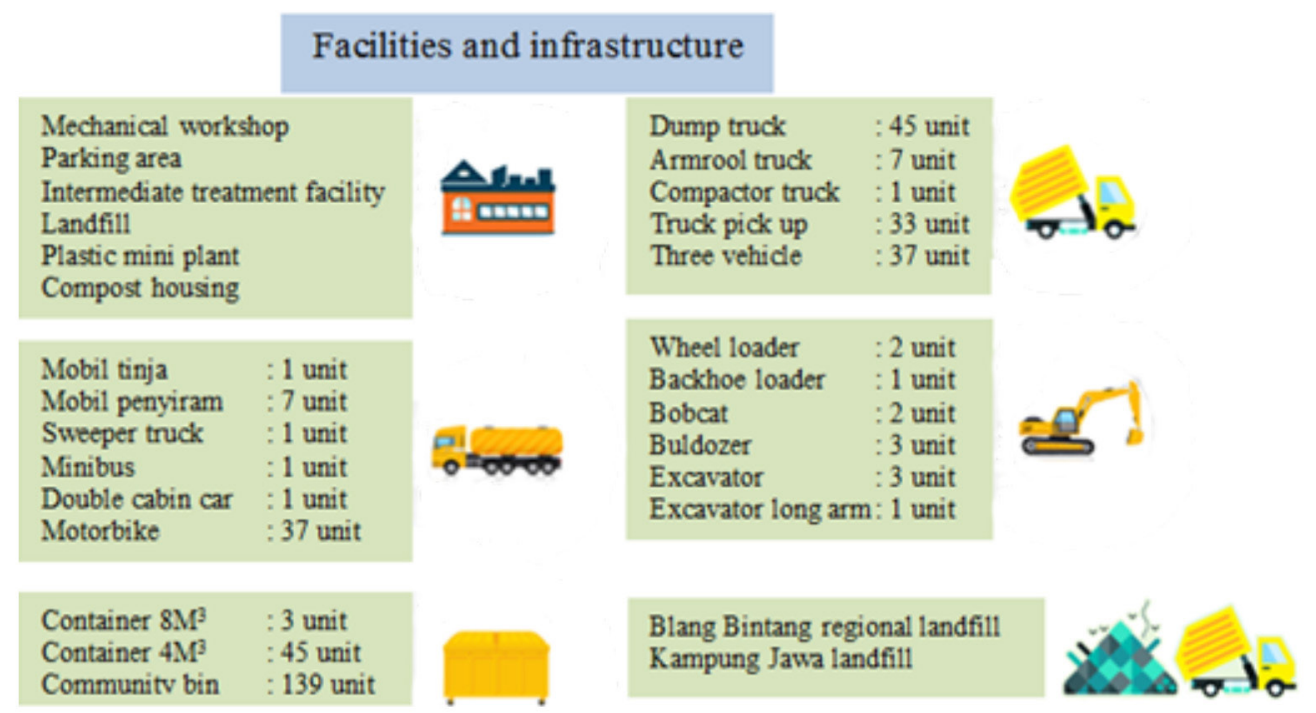

Figure 8: Facilities and infrastructure owned by DLHK3 Banda Aceh (DLHK3 Banda Aceh, 2018)

there will only be a very low chance of achieving significant waste reduction.

Moreover, none of them enjoys special priority since the implementation is often adjusted by the conditions of municipal household waste. However, it is important for the city to provide waste infrastructure and facilities prior to implementing these five aspects, especially to achieve the target of $30 \%$ waste reduction by 2025 .

Notably, the biggest waste reduction was observed to be in the TPS3R and the 3R Community Centre. Policies at the provincial level could be adopted for all regions below the regencies and cities to conduct waste management. Both the government and private sector should work together to strengthen the institutional aspect of waste management. Funds are generally required to support sustainable waste management, initiative such as waste redistribution, subsidies to collectors of used goods, and valuable 'garbage' can be adopted to reduce the waste while generating economic benefit from the programme.

On the other hand, it is evident that the level of public awareness on waste management is still at its infancy. More programmes such as waste campaign, education, promotion and appeal could be further strengthened to increase the knowledge on sustainable waste management.

\section{Acknowledgments}

The Authors thank our colleagues from Universitas Sumatera Utara, Universitas Syiah Kuala and Universitas Serambi Mekkah Indonesia who provided insight and expertise that greatly assisted the research, although they may not agree with all of the interpretations/ conclusions of this paper.

\section{Appendix. In-Depth Interview Guide}

1. Personal information (Name, Affiliation, Year of Experiment, Age, Sex, etc)

2. Are there any environmental issues, specifically in the area of waste management, that you are concerned about?

3. What are your thoughts on both the local and national waste policies?

4. What roles do institutions play in waste management?

5. Do you think funding is important in waste management? 
6. What would you suggest to increase community participation in waste management?

7. Do operational methods need to be improved in Banda Aceh?

8. From aspects no. 3 to no. 7, which is the one that you think should be stressed on foremost?

\section{References}

Babaei, A. A., Alavi, N., Goudarzi, G., Teymouri, P., Ahmadi, K., \& Rafiee, M. (2015). Household recycling knowledge, attitudes and practices towards solid waste management. Resources, Conservation and Recycling, 102, 94-100. doi:https://doi. org/10.1016/j.resconrec.2015.06.014

Badan Pusat Statistik Banda Aceh. (2018). Statistik Banda Aceh 2017. Banda Aceh.

Chakrabarti, S., Majumder, A., \& Chakrabarti, S. (2009). Public-community participation in household waste management in India: An operational approach. Habitat International, 33(1), 125-130. doi:https:// doi.org/10.1016/j.habitatint.2008.05.009

Christensen, D., \& Bach, L. T. (2015). A DanishVietnamese partnership for business and technology development in solid waste management. Resources, Conservation and Recycling, 105, 123-133. doi:https://doi. org/10.1016/j.resconrec.2015.10.019

Chung, W., \& Yeung, I. M. H. (2019). Analysis of residents' choice of waste charge methods and willingness to pay amount for solid waste management in Hong Kong. Waste Management, 96, 136-148. doi:https://doi. org/10.1016/j.wasman.2019.07.020

Damanhuri, E. (2005). Some principal issues on municipal solid waste management in Indonesia. In In expert meeting on waste management in Asia-Pacific Islands, Oct (Vol. 2729). Tokyo: Expert Meeting on Waste Management in Asia-Pacific Islands.
Das, S., Lee, S.-H., Kumar, P., Kim, K.-H., Lee, S. S., \& Bhattacharya, S. S. (2019). Solid waste management: Scope and the challenge of sustainability. Journal of Cleaner Production, 228, 658-678. doi:https://doi. org/10.1016/j.jclepro.2019.04.323

de S. Pereira, T., \& Fernandino, G. (2019). Evaluation of solid waste management sustainability of a coastal municipality from northeastern Brazil. Ocean \& Coastal Management, 179, 104839. doi:https://doi. org/10.1016/j.ocecoaman.2019.104839

Desa, A., Kadir, N. B. A., \& Yusooff, F. (2012). Waste education and awareness strategy: Towards Solid Waste Management (SWM) Program at UKM. Procedia - Social and Behavioral Sciences, 59, 47-50. doi:10.1016/j.sbspro.2012.09.244

Dhokhikah, Y., Trihadiningrum, Y., \& Sunaryo, S. (2015). Community participation in household solid waste reduction in Surabaya, Indonesia. Resources, Conservation and Recycling, 102, 153-162. doi:https://doi. org/10.1016/j.resconrec.2015.06.013

DLHK3 Banda Aceh. (2016). PROFIL DLHK3. Banda Aceh.

DLHK3 Banda Aceh. (2017a). Profil DLHK3 Kota Banda Aceh (no. Edisi I). Banda Aceh, Indonesia.

DLHK3 Banda Aceh. (2017b). Profil TPA Kampung Jawa. Repéré 28 April 2018, à http://kebersihan.bandaacehkota.go.id/1/ profil.php? $\mathrm{id}=$ profil $\&$ kode $=66 \&$ profil $=\mathrm{TP}$ A GAMPONG JAWA

DLHK3 Banda Aceh. (2018). Profil 2018 Dinas lingkungan hidup, kebersihan dan keindahan Kota Banda Aceh. Banda Aceh, Indonesia.

Elia, V., Gnoni, M. G., \& Tornese, F. (2015). Designing Pay-As-You-Throw schemes in municipal waste management services: A holistic approach. Waste Management, 44, 188-195. doi:10.1016/j. wasman.2015.07.040 
Erfani, S. M. H., Danesh, S., Karrabi, S. M., Gheibi, M., \& Nemati, S. (2019). Statistical analysis of effective variables on the performance of waste storage service using geographical information system and response surface methodology. Journal of Environmental Management, 235, 453-462. doi:https://doi.org/10.1016/j. jenvman.2019.01.061

Ferramosca, S. (2019). A worldwide empirical analysis of the accounting behaviour in the waste management sector. Waste Management, 88, 211-225. doi:https://doi. org/10.1016/j.wasman.2019.03.041

Han, H., \& Zhang, Z. (2017). The impact of the policy of municipal solid waste sourceseparated collection on waste reduction: A case study of China. Journal of Material Cycles and Waste Management, 19(1), 382-393. doi:10.1007/s10163-015-0434-3

Hietala, M., Varrio, K., Berglund, L., Soini, J., \& Oksman, K. (2018). Potential of municipal solid waste paper as raw material for production of cellulose nanofibres. Waste Management, 80, 319-326. doi:https://doi. org/10.1016/j.wasman.2018.09.033

Irwansyah, Syahputra, I., Nadir, M., \& Bakri, G. (2017). Indepth interview on waste community. Banda Aceh. unpublished.

Joshi, P., \& Visvanathan, C. (2019). Sustainable management practices of food waste in Asia: Technological and policy drivers. Journal of Environmental Management, 247, 538-550. doi:https://doi.org/10.1016/j. jenvman.2019.06.079

Kementerian Pekerjaan Umum. (2013). Materi Bidang Sampah I, Diseminasi dan Sosialisasi Keteknikan Bidang PLP. Jakarta, Indonesia: Ditjen Cipta Karya.

Kucbel, M., Raclavská, H., Růžičková, J., Švédová, B., Sassmanová, V., Drozdová, J., .. \& Juchelková, D. (2019). Properties of composts from household food waste produced in automatic composters. Journal of Environmental Management, 236,
657-666. doi:https://doi.org/10.1016/j. jenvman.2019.02.018

Kumar, S., Smith, S. R., Fowler, G., Velis, C., Kumar, S. J., Arya, S., ..., \& Cheeseman, C. (2017). Challenges and opportunities associated with waste management in India. Royal Society Open Science, 4(3), 160764.

Malik, N. K. A., Abdullah, S. H., \& Manaf, L. A. (2015). Community participation on solid waste segregation through recycling programmes in Putrajaya. Procedia Environmental Sciences, 30, 10-14. doi:https://doi.org/10.1016/j. proenv.2015.10.002

Mesjasz-Lech, A. (2019). Reverse logistics of municipal solid waste - towards zero waste cities. Transportation Research Procedia, 39, 320-332. doi:https://doi.org/10.1016/j. trpro.2019.06.034

Mohan, G., Sinha, U. K., \& Lal, M. (2016). Managing of solid waste through Public Private Partnership Model. Procedia Environmental Sciences, 35, 158-168. doi:https://doi.org/10.1016/j. proenv.2016.07.066

Nizar, M., Munir, E., Irvan \& Waller, V. (2018). The integrating of zero waste principles from national to local regulations: Case study of Banda Aceh, Indonesia. IOP Conference Series: Earth and Environmental Science, 216(1). doi:10.1088/17551315/216/1/012043

Nizar, Muhammad, Munir, E., Irvan, I., \& Amir, F. (2019). Examining the economic benefits of urban waste recycle based on zero waste concepts. In 1st Aceh Global Conference (AGC 2018). Atlantis Press.

Ogunmakinde. (2019). A review of Circular Economy Development Models in China, Germany and Japan. Recycling, 4(3), 27. doi:10.3390/recycling4030027

Pemko Banda Aceh. Peraturan Walikota Banda Aceh Nomor 7 Tahun 2017 tentang Pedoman Pelaksanaan Pengelolaan Sampah Berbasis Masyarakat dengan Sistem Waste 
Collecting Point (2017). Banda Aceh, Indonesia: DPRK Kota Banda Aceh.

Pietzsch, N., Luis, J., Ribeiro, D., \& Medeiros, J. F. De. (2017). Benefits, challenges and critical factors of success for Zero Waste : A systematic literature review. doi:10.1016/j. wasman.2017.05.004

PT. Multi Karadiguna Jasa. (2018). Final Report: Technical planning of preparation Banda Aceh City waste management. Banda Aceh, Indonesia.

Spoann, V., Fujiwara, T., Seng, B., \& Lay, C. (2018). Municipal solid waste management: Constraints and opportunities to improve capacity of local government authorities of Phnom Penh Capital. Waste Management and Research, 36(10), 985992. doi:10.1177/0734242X18785722

Tiew, K.-G., Basri, N. E. A., Deng, H., Watanabe, K., Zain, S. M., \& Wang, S. (2019). Comparative study on recycling behaviours between regular recyclers and non regular recyclers in Malaysia. Journal of Environmental Management, 237, 255263. doi:https://doi.org/10.1016/j.jenvman. 2019.02.033

Walikota Banda Aceh. Peraturan Walikota Banda Aceh No. 46 tahun 2018 tentang Kebijakan dan Strategis Pengelolaan Sampah Rumah dan Sampah Sejenis Sampah Rumah Tangga (2018). Banda Aceh, Indonesia: DPRK Kota Banda Aceh.

Wilson, D. C., Velis, C., \& Cheeseman, C. (2006). Role of informal sector recycling in waste management in developing countries. Habitat International, 30(4), 797-808. doi:https://doi.org/10.1016/j. habitatint.2005.09.005

Zaman, A. U. (2014). A comprehensive review of the development of zero waste management: Lessons learned and guidelines. Journal of Cleaner Production, 1-14. doi:10.1016/j. jclepro.2014.12.013 